\title{
DAILY HERALD V. DAILY CITIZEN,
}

I9I2-IS

\author{
THE STRUGGLE FOR A LABOUR DAILY IN \\ RELATION TO "THE LABOUR UNREST"*
}

The myth or reality of widespread social unrest in Britain in the period immediately before the First World War has attracted increasing attention among historians in recent years. Debate has centred upon two main themes, namely the character and impact of contemporary labour unrest, and the situation and prospects of the Liberal Party. Was British labour fundamentally disaffected from existing forms of industrial relations and from Parliamentary democracy? Was the pre-1914 Liberal Party already in decline and unable to withstand the advance of the Labour Party? Several recent writers have returned sceptical or largely negative conclusions to questions of this kind. ${ }^{1}$ In so doing they have sought to dispel a popularly held notion of incipient social breakdown and imminent social change, proposed amongst others by Dangerfield in The Strange Death of Liberal England.

The purpose of this article is to challenge recent opponents of the "breakdown" thesis, not so much by defending Dangerfield's approach or frame of reference as by introducing another dimension to the debate as it bears upon the problem of the "labour unrest". This concerns the emergence of labour's daily press, notably the Daily Herald and the Daily Citizen, together with the rivalry between them in the years after 1910. This theme has been largely neglected by

* This article is an amended version of a paper delivered to a conference on "The History of the British Workers Press" held at the Centre for the Study of Social History, University of Warwick, July 1972. I am especially grateful to Malcolm Bruce Glasier Esq. for access to his father's private papers.

1 E. H. Phelps Brown, The Growth of British Industrial Relations. A study from the standpoint of 1906-14 (London, 1959), ch. VI; H. Pelling, Popular Politics and Society in Late Victorian Britain (London, 1968), ch. 9; G. A. Phillips, "The Triple Industrial Alliance in 1914", in: Economic History Review, Second Series, XXIV (1971) ; P. F. Clarke, Lancashire and the New Liberalism (Cambridge, 1971); K. O. Morgan, "The New Liberalism and the Challenge of Labour: The Welsh Experience 1885-1929", in: Welsh History Review, VI (1973), No 3. 
historians of the unrest, not least by Dangerfield himself. ${ }^{1}$ The "Rebel" Daily Herald, and the "official" Daily Citizen are significant nonetheless, not merely as under-utilised sources of evidence about contemporary attitudes, but also as organisers of activity and opinion in their own right. A close study of their operation reveals a great deal not only about the extent and limits of militant unrest, but also about the dynamics of social conflict and social control within the labour movement and society at this time. It suggests both that the character and impact of militant opinion may have been misconceived and thereby under-estimated in several respects, and that the strength and cohesion of moderate Labour opinion may not have been fully appreciated.

Organised labour had become increasingly concerned with the need for a daily press outlet since the turn of the century. As the scope and influence of mass circulation daily newspapers expanded from 1890 onwards, labour felt unrepresented (or under-represented) on a number of key issues. These included the reform of Trade Union law in the aftermath of Taff Vale, the accurate reporting of trade union aspirations during industrial disputes, and proper publicity for the Labour Party's electoral programme and Parliamentary activities. Unfavourable comparisons between the backwardness of the British labour press and the scale of German labour's newspaper involvement were also constantly drawn. By 1909 the 79 Social Democratic papers, many of them dailies, had achieved over 1 million subscribers. ${ }^{2}$ British labour's periodical press (both weekly and monthly) still counted its sales in tens of thousands. ${ }^{3}$

The need for a British labour daily was a recurrent theme for debate

1 Dangerfield refers only once to the Herald, G. Dangerfield, The Strange Death of Liberal England (Paladin ed., London, 1970; first published 1935), p. 194. Most labour historians of the period give the Herald and Citizen a standard routine mention without any serious analysis of their significance. It is surprising, for example, to find that $\mathbf{H}$. Pelling, op. cit., in a general essay on "The Labour Unrest 1911-14", makes only one minor reference to the Citizen (p. 155), and none at all to the Herald. The most useful surveys of the Citizen occur in biographical studies of leading supporters, notably A. Marwick, Clifford Allen, The Open Conspirator (Edinburgh, 1964), and L. Thompson, The Enthusiasts. A Biography of John and Katherine Bruce Glasier (London, 1971). The evolution of the Herald until the mid-1920's is the subject of G. Lansbury, The Miracle of Fleet Street (London, 1925). Subsequent literature on this period has added very little to this account.

${ }^{2} \mathrm{G}$. Roth, The Social Democrats in Imperial Germany. A Study in Workingclass Isolation and National Integration (Totowa, 1963), pp. 246-7.

3 The Clarion, best-selling of the weeklies reached a circulation of 70,000 at its peak (Clarion, 16 February 1906). The ILP's Labour Leader sold between 40,000-50,000 by 1911 (Fenner Brockway to author, 19 May 1972). 
at the TUC Annual Congress from 1903 onwards, though little concrete progress was made towards publication until 1911. A variety of schemes had been put before Congress calling for a daily, weekly or monthly newspaper, but each had failed to secure the active support of affiliated unions. ${ }^{1}$ The main reasons for this were financial and political. Most trade unions were unready to risk financing a daily paper whose viability was unproven in terms of potential readership. The problem became worse during the economic recession of 1908-09. Early schemes to launch a labour daily came to a head at this time precisely when union funds were being depleted in many trades to pay unemployment benefit.

While financial considerations were prominent in public discussion, one suspects there were also underlying political doubts about the value of a distinctive labour paper among the more moderate trade union officials of Lib-Lab or Liberal persuasion. Many already had access to sympathetic Liberal daily papers. The keenest supporters of a labour daily at this stage tended also to be the sharpest critics of Liberalism, and Labour's lack of independence in relations with the Liberal Party. T. E. Naylor of the London Compositors, a leading advocate of the labour daily project, forecast that genuine pressure for a labour press would only emerge when Labour's relations with Liberalism came under closer and more critical scrutiny.

"We have received a large measure of support from the Liberal daily Press", he told the TUC Congress in 1907, "but that support has all the time been given in a halting kind of way. [...] The day will come when the line of demarcation between Liberalism and Labour will become more marked than it is today, and then you will have the daily Press against the Labour movement, and you cannot hope to maintain your fight under such conditions. You have no control over, practically no influence upon, the opinions expressed on behalf of Labour in the Liberal Press today, and how much longer are you going to be satisfied with opinions that are filtered through Liberal channels?"2

Naylor's prediction was vindicated in part with the onset of the "labour unrest" from 1910-14. The emergence of a labour daily press after 1910 reflected a growing crisis within the labour movement over the utility of prevailing forms of industrial and political activity. Widespread industrial conflict in 1910 and 1911 provoked many to discuss the value of aggressive strike action and radical trade union

1 The details can be followed in TUC Annual Conference Reports, 1903-1909.

2 Ibid., 1907, pp. 162-3. 
reorganisation, as against existing forms (or ideals) of conciliatory collective bargaining and partnership with capital. Discontent went further however to involve the merits of revolutionary syndicalism as an alternative means of social change to collectivist legislation achieved through Parliamentary politics. Hostility towards existing trade union policies became combined with a growing unease with the Parliamentary Labour leadership and its accommodation with the Liberals. The Daily Herald, first of the two labour dailies to appear, soon became an important medium through which the challenge to Labourism and Liberalism was articulated.

The Daily Herald first appeared in January 1911 as the news-sheet of the London printing unions, currently engaged in a protracted industrial dispute. The paper was intended in the first instance as a means of counteracting the hostility of the existing daily press to the print workers claims for a 48 hour working week. Particular cases of press distortion were located in the Liberal Daily News. While the Herald functioned initially as a dispute sheet, it soon extended its coverage to include general political and industrial news, and features on recreational topics like cycling, gardening and football. Distribution was also extended outside London to the provinces. ${ }^{1}$ This was partly a response to the widening of the printers' dispute to involve provincial centres, but it also represented a definite movement among the paper's supporters to achieve national status as a fully-fledged labour daily. The London printing unions had always been the leading advocates for a labour daily at the TUC. Their ambition and drive now prompted sympathetic support from many others outside the trade. By April 1911, the paper's sponsors felt sufficiently confident to print detailed plans for a reconstituted Daily Herald. ${ }^{2}$ This attempt was however premature, as the paper ceased publication before the new venture was established. The continuation of labour unrest throughout 1911 and the early part of 1912 nevertheless encouraged its eventual reappearance as a national labour daily in April 1912.

From the outset, the new Daily Herald functioned in an independent manner, outside the control of the main organs and established leadership of the labour movement. Though it received support for a while from the TUC Parliamentary Committee, this in no way entailed external control over editorial policy during this period. The first 10-man management committee included only 2 TUC representatives, the remainder being composed in the main of prominent London trade

1 By mid-February, the paper was available in Manchester, Preston, Leeds, Belfast and Dublin, as well as throughout London and the Home Counties. Daily Herald, 14-15 February 1911.

2 Ibid., 10, 19, 21 and 28 April 1911. 
unionists. Within the management committee, however, the influence of militant opinion was uppermost, centring, in the beginning, on the figures of George Lansbury and Ben Tillett. This influence led to the recruitment of radically-minded propagandists to editorial positions. ${ }^{1}$

The political independence of the early Herald stemmed from the conviction of its leading sponsors that contemporary unrest demanded a forum-style newspaper to debate the various issues raised. The success of their approach depended very largely on rank-and-file initiative in determining the political content of the paper through correspondence, feature articles and local reports. This formula did not however mean complete editorial neutrality between viewpoints, but rather a determined refusal to become aligned with any narrow set of precepts subsumed under the notion of party wisdom and orthodoxy. Such independence required the Herald's non-alignment both with the Labour Party and with the parties of the socialist left, including the newly-formed British Socialist Party (BSP).

"Our weekly Socialist and Labour journals have become far too partisan and have thought very much more of the party they represented, than of the cause itself", wrote Lansbury. "The Socialist Movement, especially, has been in danger and is still in danger of being smothered by dogma. [...] In the Daily Herald, Trade Unionists and Socialists of every creed and kin, Parliamentary and anti-Parliamentary, Syndicalist and Non-Syndicalist, will have room and scope fairly to state their ideas in their own way. No committee and no editor will edit the people's opinions. [...] We want to have thrashed out in a perfectly friendly manner, those questions connected not only with the theory of the general strike, or the right to strike, but the fundamental utility of the general strike, as a Labour weapon. We also want thrashed out - and this requires to be done very quickly - the question as to why it is and with what object we send Labour and Socialist members to the House of Commons." 2

1 The TUC's two representatives were C. W. Bowerman, MP, Secretary of the Parliamentary Committee, and W. Matkin, General Secretary of the General Union of Carpenters and Joiners. Radical editors included Rowland Kenney, who had previously been associated with the Labour Leader and New Age (R. Kenney, Westering (London, 1939), pp. 143ff.), and Charles Lapworth, who had radical journalistic experience in Britain and the USA (G. Lansbury, The Miracle of Fleet Street, p. 32). Lapworth was almost succeeded as editor by Rebecca West, leading woman writer for the Clarion. Eventually, however, Lansbury took over himself. Henry Harben to Raymond Postgate, 13 November 1948, Lansbury Papers, Vol. 28, Appendix b ii, British Library of Political and Economic Science.

2 G. Lansbury, "Scope for All in Labour's Daily Press", in: Daily Herald, 16 April 1912. 
The Herald's commitment to open access was upheld not only by Lansbury, but by other dissidents from the party system including the prominent syndicalist Tom Mann. Sectional attempts to bind the paper to a rigid political strategy or exclusive readership appeal were resisted by the leading sponsors. ${ }^{1}$

While the columns of the Herald were genuinely open to all at this time, the paper's editorial policy was keenly orientated towards specific currents of dissidence or unease within the labour unrest. Militant opinion and discontent was generally given pride of place in debate with Liberal, Labour and Socialist orthodoxies. Within the general climate of unrest, the aspirations of a wide range of social movements were both monitored and co-ordinated by the paper. Such movements were located not merely within the "labour movement" as it is traditionally conceived, but also within a variety of additional movements whose activities and personnel did not over-lap in any precise way with tangible labour institutions. Within the "labour movement" the most prominent dissident movements associated with the Herald were syndicalism and Guild Socialism. Their supporters were drawn from a wide orbit including the ILP, BSP, Fabian Society and many trade unions. Other groupings allied with the paper included sections of Christian Socialist opinion, some segments of the women's suffrage campaign, and certain advocates of the distributivist social philosophy.

The various elements of contemporary dissidence are often treated as discrete movements showing little significant inter-connection in thought or in action. The varying strength of their "separate" influences on the Herald over time, is often seen as the explanation of changing emphases in the paper," or less charitably of "inconsistency" or "confusion" in policy. ${ }^{3}$ This approach is however misleading. While a variety of intellectual traditions, value-systems and social objectives were to be found within dissident social movements, there existed

1 The most serious attempt of this kind involved an increasingly sectarian grouping within the syndicalist movement, represented on the Herald by Charles Lapworth. For circumstances leading to the ousting of Lapworth see G. Lansbury, The Miracle of Fleet Street, pp. 32-34. Tom Mann in contrast while "He did not agree with all that appeared in the Daily Herald, [...] did not want the views of his own little crowd to be always appearing in its columns", Daily Herald, 23 November 1912.

2 R. Postgate, The Life of George Lansbury (London, 1951), pp. 138-140.

3 Beatrice Webb saw the Herald as "Iconoclastic and inconsistent in the policies it takes up and drops with fiery levity". Beatrice Webb's Diaries 1912-24 (London, 1952), p. 23. For a somewhat similar Leninist appraisal see R. Fox, The Class Struggle in Britain in the Epoch of Imperialism, 1 : 1880-1914 (London, 1932), p. 93. 
between them - at least in the short term before the outbreak of war in 1914 - a considerable degree of cross-fertilisation of ideas and interconnection of personnel in debate and action. Criticisms of modern industrial capitalism, Parliamentary democracy, Liberal social reform, and the party system, brought about a converging set of concerns and alternative aspirations among movements which often started from divergent premises. Dissidents from a variety of backgrounds were able not merely to co-operate in a spirit of mutual support, but also to draw inspiration and ideological cohesion from each other.

Significant differences certainly existed within this range of social movements. The most divisive occurred between the distributivists, like Hilaire Belloc and G. K. Chesterton, and the suffragettes over the value of the women's suffrage agitation. A less divisive but more fundamental philosophical difference existed between distributivists and syndicalists over the shape of the new social order. Where the distributivists relied upon diffused property ownership as the necessary counterweight to capitalist wage slavery and state collectivism, the syndicalists looked in contrast to revolutionary industrial organisation both as the agency of social emancipation, and as the embryo of a new social order.

The inter-connections between movements were sufficient, nonetheless, to preclude deep division on most occasions. The repressive behaviour of the Liberal Government towards dissident radicals helped to sustain mutual co-operation or at the very least respect. Individual social movements, while retaining their own identity and freedom of action, were nevertheless prepared to participate in the all-embracing "rebel" movement as co-ordinated in and around the Herald. This being so, it becomes misleading to picture a number of individual movements exerting competing and mutually exclusive influences upon a paper which could not decide between them. Instead there existed an overlap between movements and partial merging of influences which were very often complementary rather than conflicting. The Herald's forum style was in any case deliberately chosen and cannot be regarded as the product of "inconsistency" or "confusion". It reflected not merely the urgent need for debate raised by the labour unrest, but also a widespread concern to maximise unity among the dissidents.

The involvement of distributivists with the Herald marks one of the most important though least explored cross-connections within contemporary unrest. The Belloc-Chesterton critique of Parliamentary and party politics and opposition to Liberal social reform became a 
central point of debate within the paper. ${ }^{1}$ Belloc, a former Liberal MP, whose pivotal book The Servile State was published in 1912, contributed on several occasions to the Herald. The two Chesterton brothers - Cecil and Gilbert - were similarly involved. Cecil, an active Fabian, was for a time involved in editorial work and Herald-sponsored meetings, while Gilbert wrote a weekly column from 1913 well into the War. The distributivist connection with dissident opinion extended wider than this, however, notably through their weekly periodical The Eye Witness (later The NewWitness). This was edited first by Belloc and later by Cecil Chesterton. A constant flow of ideas circulated between the two papers, with Lansbury and close associates contributing on several occasions to The New Witness. ${ }^{2}$ Joint support was given to contemporary industrial militants and to opponents of conventional party politics as a means of redress for social problems. The distributivists' journalistic assault on Liberal Government corruption during the Marconi Scandal was particularly welcomed. ${ }^{3}$

Support for the views of Belloc and Chesterton was considerable among dissidents within the Labour Movement. This extended through syndicalist, Guild Socialist, and dissident Fabian opinion. George Simpson, northern organiser of the Industrial Syndicalist Education League (ISEL) felt that the advent of The Eye Witness and the exposures of the Party system by Belloc and Chesterton had together with "the brilliant articles in 'The New Age' on Guild-Socialism [...] created quite a new mental atmosphere". Jack Wills, a leading London-based syndicalist in the building trades, used Belloc's analysis in practical agitation against Liberal social welfare legislation. ${ }^{4}$ The common campaign against Liberal social reform created a close crossfertilisation of ideas between distributivists and other dissidents.

Such opponents of Liberal social policies saw contemporary legislation as a new form of capitalist repression organised through bureaucratic state control. Social welfare schemes might be sufficient to

${ }^{1}$ Belloc and Cecil Chesterton were joint authors of The Party System (London, 1911). Belloc went on to publish The Servile State (London, 1912). This was the central statement of the distributivist philosophy. It developed out of a debate with Ramsay MacDonald held in London, and was published in 1911 under the title Socialism and the Servile State by the SW London Federation of the ILP. 2 See in particular G. Lansbury, letter in New Witness, 5 December 1912; "Is Parliament Useless?", ibid., 19 December 1912; Edgar Lansbury, "Bow and Bromley Election", ibid., 13 February 1913.

${ }^{3}$ For favourable reviews of the New Witness in the Herald see ibid., 16 December 1912 and 3 January 1913.

4 George Simpson, letter in Daily Herald, 3 January 1913; J. Wills, "An Exposure of Labour Exchanges", in: Solidarity, September 1913; and "Insurance Revelations", ibid., December 1913. 
undermine unrest, but would not solve the fundamental social problems of poverty and lack of genuine industrial and political democracy. The result would be a passive dependent population more closely disciplined in capitalist interests. Belloc saw the 1912 national insurance legislation, for example, as part of the rapidly approaching "Servile State", designed in this case,

"To capture organised labour and to cut its claws. It is particularly meant, after the experience of last year to destroy the powers of the Trade Unions, and to make it difficult and later impossible for workmen to strike."1

The majority of Herald readers supported Belloc in this view, but felt that his critique of Liberal social reform might well be supplemented by syndicalist prescriptions for effective opposition. "What Labour M.P.s and Trade Union leaders have failed to do towards killing the Act, Mr. Belloc has done", wrote a London clerical worker. "After hammering the Bill for months he very clearly demonstrates what a pernicious and horrible thing this Act is. [...] Union leaders must act at once and it is up to the Unionists to see that they do it. Our watchword should be Direct Action".2 Lansbury felt that "unless we are quickly up and doing, Belloc's Servile State will be in full swing in the lifetime of many of us", but that "the present type of Liberal legislation may cause the nation to degenerate into a spoon-fed people, but the new Syndicalist movement will probably save us from that". 3

Another reader hinted at the contribution of the Herald as a medium by which cross-currents between syndicalism and the Belloc critique were developed:

"Let anyone consider the influence of the Herald day after day imparting, sub-consciously it may be, its note of rebellion and independence. Day after day its records of the uprisings of the workers give an intimate sense of labour struggling and show the need for solidarity and action on a large scale. Its opposition to paternalism daily reiterated will make labour critical and suspicious of reform dopes like the Insurance Acts, and compulsory arbitration will be examined before being taken."4

The distributivists attack on collectivist social reform also led them

1 H. Belloc, letter in Daily Herald, 7 May 1912.

2 Ibid., 15 May 1912.

3 G. Lansbury, "Socialists and Socialism", ibid., 14 January 1913; speech to Worthing ILP, cited in Liverpool Forward, 27 September 1912.

- A. O'Donnell, letter in Daily Herald, 28 October 1912. 
to challenge revolutionary socialists on the projected place of the state in the new social order. Did the "old sovereign remedy" of socialising the means of production mean state capitalism or some more genuine form of popular control, asked Cecil Chesterton in The New Witness. ${ }^{1}$ Revolutionary opinion seemed unclear to him on this issue. He ascribed this to a decline in the militant character of socialism over recent years. Though distributivism looked to a new society based on diffused property ownership, Chesterton's challenge provoked other dissidents to define what socialism meant to them. The Herald carried an extensive debate on this question under the title "Is Socialism Dead?" During the course of this debate many contributors were prepared to identify their own socialist commitment with the anticollectivist stand in Chesterton's thinking. For them, socialisation of the means of production, did not mean control by a state bureaucracy. ${ }^{2}$ There were, nonetheless, some dissenters among Herald correspondents, notably Russell Smart. He found it unsatisfactory that Chesterton and Belloc should "oppose bureaucracy when it is political", yet as Roman Catholics "support bureaucracy when it is religious".

Another important cross-current within contemporary dissent linked Christian Socialists with anti-collectivist feeling derived from syndicalism, Guild Socialism, and the distributivist philosophy. The Church Socialist league (CSL) was a particularly important focus for radical churchmen. It included individuals like Maurice Reckitt, currently moving away from Fabian collectivism towards dissident strands of contemporary unrest. He, like many others, found inspiration consistent with Christianity among Guild Socialists and the Belloc-Chesterton current. Writing of The Servile State, Reckitt recalls: "I cannot overestimate the impact of this book upon my mind and in this I was but symptomatic of others who had passed through the same phases as I had." 4 Under influences like these, the CSL Annual Conference of 1912 had "Welcomed the 'Labour Unrest' as indicating the Revolt of the People against industrial injustice and social wrong. $[\ldots]$ it is the duty of the Church to abandon its profession of neutrality and openly further the revolt."

Rev. Conrad Noel, vicar of Thaxted and prominent member both of the CSL and BSP identified the movement's "deadliest foes" as

1 C. Chesterton, review of H. Hyndman's Reminiscences, in: New Witness, 19 December 1912, reprinted in Daily Herald, 20 December 1912.

2 For favourable reception see especially T. Mann, "Is a Syndicalist a Socialist?", in: Daily Herald, 28 December 1912; L. Hall, "The End of Socialism", ibid., 11 January 1913; G. Lansbury, "Socialists and Socialism", ibid., 13 January 1913. " R. Smart, "The Cecilian Revolt", ibid., 4 January 1913.

- M. Reckitt, As It Happened: An Autobiography (London, 1941), p. 108. 
"The Daily Press, the Liberal Government, the Party System, and the Religious Newspapers". Hope for the future lay in "The revolt of the people against their 'leaders' as manifest in sympathetic strikes and the general labour unrest". ${ }^{1}$ Hostility to the existing daily press pointed the way towards Christian Socialist involvement with the Herald. Many CSL members supported and actively worked for the paper including Noel and of course Lansbury, elected president of the League in 1912. Other CSL Heraldites included Rev. Frank Swan, minister of the Brotherhood Church, Southgate, who was involved in editorial work and propaganda meetings, ${ }^{2}$ and also Rev. W. H. Paine who gave considerable financial assistance. CSL branches also gave financial support.

A further cross-current within the unrest linked sections of the militant women's suffrage movement with other dissidents. The Herald once again stimulated contact and cross-fertilisation of concerns. The main groups involved were the Women's Social and Political Union (WSPU) and the Women's Freedom League (WFL). Both welcomed the appearance of the paper as a radical forum, and were keen to take up the Herald's offer of column space to publicise their activities and debate with others. A London WSPU member declared that "What had drawn her into the movement in support of the Herald was the splendid uncompromising spirit manifested towards the women's cause primarily, and also for the workers movement generally." 3 Christabel Pankhurst at the centre saw in the Herald "A band of people who will honestly give effect to the best Labour and Socialist ideals". " Her only worry was that the anti-suffragette Belloc-Chesterton current might become influential within the paper. This concern was to prompt a wide and sometimes bitter debate among suffragettes and other dissidents, most of whom sided with Pankhurst.

In the meantime, WSPU and WFL members continued to support the Herald by financial donation and sales publicity. The closest links between suffragettes and dissident opinion centred almost certainly on Lansbury. This connection reached its zenith in his resignation from Parliament in 1912 to fight on the suffrage issue. After his failure to gain re-election, contact continued though relations with the mainstream of the WSPU at least seem to have deteriorated by the

1 Cited in P. d'A. Jones, The Christian Socialist Revival 1877-1914 (Princeton, 1968), pp. 271, 243.

${ }^{2}$ Swan was a regular chairman of Herald meetings, see, for example, Daily Herald, 6, 13 and 16 December 1912. Also P. d'A. Jones, op. cit., pp. 424-425.

${ }^{3}$ Mrs Penn-Gaskell at Kilburn, reported in Daily Herald, 10 January 1913.

4 Christabel Pankhurst to George Lansbury, 8 December 1912, Lansbury Papers, Vol. 28, fol. 99. 
outbreak of war. The autonomous East London movement led by Sylvia Pankhurst continued nonetheless to work closely with local Herald activists. This connection depended on the suffragettes' concern for aspects of women's emancipation other than the vote, e.g. women's trade unionism, and thereby, for contact with the labour movement. ${ }^{1}$ Contact of this kind was to survive and prosper during the First World War.

Inter-connections within the unrest between distributivists, Christian Socialists and militant suffragettes drew heavily, as already indicated, on the inspiration of contemporary industrial militancy. The upsurge of rank-and-file discontent between 1910-14 prompted considerable thought within dissident circles as to the value of strike action. The emergence of syndicalism and Guild Socialism on a significant scale was an attempt to develop alternate anti-collectivist solutions in the wake of official Labour's accommodation with Liberalism. The Herald, as is often mentioned, played an important part in debating the contribution of both movements, though the effect of this publicity has been less well explored. The impact of both movements on dissident opinion was significantly enhanced by $\mathrm{Herald}$ coverage, more especially so in the case of syndicalism.

Guild Socialism, whose appeal as yet derived very largely from felt inadequacies in the Fabian strategy of collectivism, ${ }^{2}$ made most of its converts among educated middle-class opinion at this time. G. D. H. Cole and William Mellor, two of the more energetic young supporters, were the earliest Guild Socialist contributors to the Herald from 1914 onwards, taking a regular column during the war. ${ }^{3}$ While their contributions were widely read, it remains true that the main impact of Guild Socialism was felt elsewhere through the columns of the New $A g e$ and within the Fabian Society. The role of the Herald as a publicist for syndicalist views was more significant. The meaning and utility of syndicalism was a topic for debate within the paper from its inception. This emphasis was stimulated at the editorial level by Charles Lapworth, ${ }^{4}$ himself a committed syndicalist, and by Lansbury. Prominent syndicalists like Tom Mann, Guy Bowman and A. D. Lewis were involved as contributors and Herald publicists from 1912, while

${ }^{1}$ E. S. Pankhurst, "What is the East London Federation?", in: Women's Dreadnought, 8 March 1914. Also E. S. Pankhurst, The Suffragette Movement (London, 1931), pp. 502ff., and G. Lansbury, The Miracle of Fleet Street, pp. 79-85.

M. Cole, "Guild Socialism and the Labour Research Department", in: Essays in Labour History 1886-1923, ed. by A. Briggs and J. Saville (London, 1971).

${ }^{3}$ G. D. H. Cole and W. Mellor in Daily Herald, 13 January 1914 et seq.

4 Lapworth had previously been a publicist with Eugene Debs, co-founder of the IWW. H. Pelling, America and the British Left (London, 1956), p. 105. 
many rank-and-file syndicalists gave financial support. ${ }^{1}$ By these means the Herald not only gave the syndicalists' objectives a wider national publicity than was possible within their own monthly press and outdoor agitation, but also helped to create through its correspondence columns and news reports, a sense of syndicalism as a coherent movement. Last, and perhaps more important, the Herald's emphasis on syndicalism helped to encourage a cross-fertilisation between revolutionary industrial thought and other currents of dissidence. Syndicalism became, in the words of a contemporary activist "part and parcel of the left wing approach". ${ }^{2}$

The rival Daily Citizen first appeared in October 1912. Its foundation was not merely an official response to the radical impact of the Herald, but also represented the culmination of long-felt aspirations for a labour daily within the ILP. It was Keir Hardie who early in 1911 began practical preparations for a specifically socialist daily controlled by the ILP. ${ }^{3}$ This scheme, which found favour with the ILP Conference rank-and-file differed substantially from the approach of the Labour Party leadership towards any projected paper. Ramsay MacDonald, for example, argued in favour of a general progressive rather than a specifically Socialist venture. This should be under the joint control of the ILP and the Labour Party. Such a paper would enable the leadership to re-assert and develop support for existing policies currently under attack from dissident opinion.

It was MacDonald's approach which eventually won the day, largely because the majority of ILP leaders could as yet see no likelihood of tension between ILP and the Labour Party over control of policy. Accordingly an agreement between leading representatives of the two organisations was signed in May 1911. This laid down that

"The policy of the paper shall be frankly in accord with the alliance of Trade Unionists and Socialists as embodied in the Labour Party. Its leading articles shall voice the policy of the movement as a whole, on the political and industrial issues of the day. It shall give prominence to the speeches and work of

\footnotetext{
1 A. D. Lewis, a prominent member of the Industrial Syndicalist Education League, became national secretary of the Daily Herald League. For documentation of rank-and-file syndicalist involvement see below.

2 Arthur Grardiner, former member of Huddersfield Socialist Party in which the syndicalist influence was significant. Interview by Cyril Pearce, letters to author, 5 December 1970 and 8 April 1971.

3 Keir Hardie to Bruce Glasier, 1 January, 8 February and 17 May 1911, Bruce Glasier Papers in the possession of Malcolm Bruce Glasier Esq.; ILP Annual Conference Report, 1911, pp. 88ff.
} 
the Party in Parliament. For the rest it shall fulfil the ordinary functions of a newspaper giving Trade Union, Labour and Socialist news. Adequate space shall be devoted to sport and recreation, but [and this was the only real concession to the ILP] no betting or gambling tips shall be allowed in its columns."

This agreement was subsequently ratified by the ILP National Council, at which point Hardie withdrew completely from the project.

Tension between Labour Party pragmatism and the more clear-cut ILP commitment to Socialist principle became more obvious as preparations for publication were organised. Originally ILP representatives within the Citizen scheme interpreted Hardie's hostility to the MacDonald approach as a personality issue rather than a political disagreement. ${ }^{1}$ This false impression was soon dispelled, however, once the intentions of MacDonald and his associates became more clearly defined.

"I noticed", wrote Bruce Glasier, "that MacDonald in speaking of the appeal we should send out for capital used the word 'Democratic' rather than 'Labour' or 'Socialist' as describing the character of the paper. I rebuked him flatly and said we would have no 'Democratic' paper, but a Socialist and Labour one boldly proclaimed."2

Tension between Labour Party and the ILP was further registered later in 1911 during election for chairman of the Citizen's board of directors, (incorporated as Labour Newspapers Ltd.). MacDonald now defeated the prominent ILP radical W. C. Anderson by three votes to two. ${ }^{3}$ In spite of internal disagreement, practical arrangements for publication went ahead. By October 1911, a share prospectus had been issued and $£ 26,000$ subscribed. Clifford Allen, the energetic young Cambridge Fabian, had also become full-time fund-raiser and canvasser.

The early character of the Daily Citizen, finally launched in October 1912, confirmed the predominance of Labour Party pragmatism in editorial policy. The paper, working along the lines developed by the Parliamentary Labour leadership at Westminster, sought above all else respectability and wider acceptance within the existing political culture. The Citizen's first edition was devoted in fact to testimonials from non-labour personalities presented as "leaders of public opinion". "I think it very essential to the welfare of this Empire", wrote Lord Northcliffe in the leading testimonial, "that Labour should have a

1 Bruce Glasier, Diary, 5 May 1911, Bruce Glasier Papers.

2 Ibid., 1 June 1911.

s Ibid., 19 December 1911. 
proper newspaper. We have the only representative Parliament in the world, and I should like to see a really representative Press." He went on to emphasise the value of the Citizen "to employers as well as to the men. In the modern organisation of capital and labour on its present vast scale, it is quite impossible for the organiser to meet the workers in the way they were able to in smaller times."1

The paper's sponsors, like Northcliffe, were aware of the Citizen's potential function as an agency of social control within the labour movement. The mass circulation press was beginning to be seen as a replacement for older face-to-face contact, as a means of "making opinion", and, in this specific context, in the moderation of class tensions within the labour unrest. The Citizen's first leader had, it is true, claimed the paper as "The voice of that hitherto almost inarticulate movement of working-class feeling which is represented in Parliament by the Labour Party, and in the country by the innumerable efforts, suspicions, resentments and claims which together make up what is known as the Labour Unrest". ${ }^{2}$ In practice, however, the presentation of representative "voices" in the paper was severely restricted to orthodox opinion centred on Labour Party pragmatism. ${ }^{3}$ In contrast to the Herald, editorial initiative was narrowly based and came from above. It was geared to the incorporation of labour unrest into conciliatory forms of protest and pressure, harmonising relations between labour and capital, and re-directing energy towards the Parliamentary area.

The Citizen's defence of Labourism led to concern both with parliamentary political and trade union activity. In its early days, however, the emphasis was primarily on positive reform through political methods. The Citizen, under the control of the Labour Party and ILP, had been presented to the TUC Congress in 1911 as "the Labour Party scheme" designed to "Do justice to the work of your Labour Members in the House of Commons". Prominent trade union leaders were as yet sparsely represented on the board of directors, the exception being John Hodge of the Steel Smelters. The TUC Parliamentary Committee in fact took greater interest in the Herald, at least until 1913. This was partly due to the paper's origins within the trade union movement, and also, of course, because it was first in the field as a labour daily.

1 Daily Citizen, 8 October 1912. Other testimonials were received from Robert Donald, editor of the Liberal Daily Chronicle, the Lord Provost of Glasgow, and the Bishop of Birmingham.

2 "The Daily Citizen And Its Work", ibid., 8 October 1912.

3 Fred Jowett, MP, representative of a rival current of thinking within the Labour Party felt that "The editor of the Citizen seems to think that nobody counts in the Labour Party but the Chairman Mr. MacDonald". Clarion, 29 November 1912. 
Subsequently the Herald's radical anti-establishment views as applied to Labour and Trade Union leaders, soon began to alienate TUC opinion. Even strong Herald supporters like C. Bowerman and T. E. Naylor now argued in favour of the co-existence of the two labour dailies. ${ }^{1}$

The Citizen's predominantly Parliamentary focus was reflected by the decision to launch the paper at the beginning of the autumn Parliamentary session. Clifford Allen justified this on the grounds that "interest in politics and everything serious lags during the summer months". Politics in this view only became "the principal topic of conversation" when Parliament was in session. ${ }^{2}$ This approach seemed orientated towards the world of Westminster legislators and professional opinion-makers, rather than labour activists uninvolved in the summer "season". Its promotion was one aspect of the process of social control mounted by the Citizen, by which popular attitudes towards the powerstructure and decision making in society were to be shaped. Some of the paper's supporters remained unconvinced. During the summer Allen had to defend the approach against critics who felt that current industrial unrest among miners and transport workers was equally significant as an example of class conflict and the resolution of power struggle. ${ }^{3}$ In their view the paper should be brought out immediately to monitor this aspect of the labour unrest.

Alongside the Parliamentary emphasis, contemporary problems of industrial relations and trade unions became an increasingly important concern of the Citizen. Two main pressures were at work here. On the one side was the widely felt need to counteract the hostility of the existing press in the reporting of industrial disputes. On the other side, the paper was designed to challenge the value of militant industrial action, as an aggressive strategy for social emancipation. The Citizen's leaders upon the problem of industrial unrest were careful, therefore, to temper their support for the aspirations of strikers with articulate opposition to contemporary syndicalist methods of direct action. Strikes (including the sympathetic strike) were seen as necessary only as a defensive method of last resort. At all times the authority of union leaders was upheld over unofficial or spontaneous outbreaks of rank-and-file discontent. ${ }^{4}$ Some moderate leaders felt that such "wise

1 TUC Annual Conference Report, 1912, p. 144; Daily Citizen, 8 March 1913.

2 C. Allen, "Daily Citizen", in: Labour Leader, 19 April 1912.

${ }^{3}$ Especially H. Pickles (Colne), letter in Labour Leader, 3 May 1912.

4 "The Sympathetic Strike", in: Daily Citizen, 18 September 1913; "Do Strikes Pay", ibid., 20 September 1913; "Forward", ibid., 12 November 1913; "The South Wales Strike", ibid, 5 December 1913; "Union, Municipality and State", ibid., 18 December 1913. 
councils" had prevented more wide-spread strike action during periods of unrest, but this claim is difficult to substantiate. ${ }^{1}$ In the final analysis, however, the main aim of the paper was to re-direct industrial activists towards political action to secure "control over the machinery of government". Unfortunately for the labour leaders, the Citizen did not survive long enough to confirm its worth as a medium for electoral propaganda.

During the short history of the Citizen from 1912-15, there is only limited evidence that the dominant tone of Labour Party pragmatism was offset by counter-vailing pressure from radical ILP opinion. The existence of such pressure cannot be doubted, stemming as it did from widespread disappointment with the paper's impact. Bruce Glasier, at boardroom level, recorded that he opened the first edition, "With trembling and glanced hastily over its pages", but "felt no thrill of joy, no sense of satisfaction. [...] A decided feeling of disappointment grew on me. No it will not do - unless it is greatly improved. It is not distinctive, its Labour and Socialist news is scrappy. It has no grip. It has no raison d'être." 2 At the rank-and-file level, a typical reaction was that of the East Ham branch of the ILP, which found the paper "taking a safe course" and "giving undue prominence to the doings of Royalty". ${ }^{3}$

Criticisms of this kind made very little impression on the policy or tone of the Citizen for several reasons. In the first place it is evident that all ILP radicals did not speak with one critical voice. Some, for example, placed general labour movement representation within the daily press, above the need for a specifically socialist paper. Others saw in the Labour alliance the only means of raising adequate finance to support the Citizen. Even if criticisms of the paper had been widespread and cohesive, it still remained difficult for dissident opinion to actually change policy. It was not just that the board of directors had a pro-MacDonald majority, but also that day-to-day editorial policy was designed autonomously by a team of professional journalists recruited from Fleet Street. This arrangement reflected the sponsors' resolve to model the Citizen as far as possible upon existing masscirculation dailies.

From its inception, the paper was intended to attract "the services of the best known and most experienced journalists of the best London

1 G. H. Roberts, MP, held this view of the paper's role during unrest on the railways. Daily Citizen, 8 March 1913.

2 Bruce Glasier, Diary, 8 October 1912.

3 East Ham ILP, branch minute, 30 October 1912, British Library of Political and Economic Science. For similar criticisms see ILP Annual Conference Report, 1914 , pp. $68 \mathrm{ff}$. 
papers". ${ }^{1}$ Frank Dilnot of Northcliffe's Daily Mail became editor, while A. G. Wright of The Times became manager. Neither was a committed labour activist. ${ }^{2}$ Accordingly the Citizen's editorial staff placed considerable emphasis within the paper on the standard preoccupations of the popular daily press. Apart from the usual "obsession with Royalty" and macabre crimes of violence, these soon came to include a comprehensive betting service for punters. It was at this point that the constraints of ILP influence of an ethical character met with open failure.

The original Labour Party-ILP agreement of May 1911 specifically excluded racing tips and betting news within the paper. By mid-1913, however, the Citizen's professional staff found this ban a considerable obstacle to circulation improvement. "The editor, manager, and circulation agent have declared that without betting news, the paper cannot go on", wrote Glasier. "All the directors are personally against betting, but several have for some time been insisting that it is necessary to yield to this foible of the working class." In the end it was agreed by majority vote that a betting service be included. This prompted the resignation of ILP members Arthur Henderson and W. C. Anderson from the board. ${ }^{3}$ ILP pacifists were to suffer an equally significant defeat over the Citizen's patriotic coverage of Britain's war effort after August 1914.

The conflicting ideological stance of the two labour dailies brought equally contrasting intentions with respect to business organisation, financial structure and circulation policy. Where the Citizen wished to adopt "modern business methods" in the light of the "Northcliffe Revolution", the Herald was content to draw upon the enthusiasm of its activist supporters for finance and publicity. In practice, the Citizen was unable to depend exclusively on commercial methods, and was forced like the Herald to rely very largely on the voluntary support of its readership. A comparative study of mass involvement with the financial and circulation problems of the Herald and Citizen provides further confirmation of the ideological character of both papers, discussed above, and gives some indication of the scale of rank-and-file support.

1 J. Ramsay MacDonald to Labour Newspapers Ltd. first shareholders meeting, Labour Leader, 27 June 1912.

2 Glasier described Wright as "A commonplace commercial money-grabber". Diary, 3 October 1912. Arthur Marwick on the basis of Clifford Allen's views saw Dilnot as "A chain-smoking professional journalist [...] but not a socialist", op. cit., p. 16.

3 Bruce Glasier, Diary, 18 June 1913. 
The careful organisational and financial planning behind the Citizen project, contrasted sharply with the ad hoc business methods of the early Herald. Where the Citizen's sponsors allowed a period of 18 months before publication for capital accumulation and circulation preparations, the Herald began with very little prior organisation or thought for the problems of long term survival. Adequate financial provision was nonetheless, a constant preoccupation for both papers, launched, as they were, during a period when scarcely any of the main London dailies was returning a profit. Both the Herald and the Citizen had almost collapsed under the weight of financial difficulties before 1914.

Standard financial provision for launching a daily paper involved two elements, the accumulation of a capital sum sufficient to meet fixed capital costs and initial expenses, and the generation of adequate revenue from publication to finance running costs. The Citizen's assimilation to "modern business methods" involved careful planning to overcome both these problems. In the first place, initial capital requirements were to be met out of an accumulated sum of $£ 100,000$. Thereafter operating costs were to be financed very largely on the Northcliffe model, on the proceeds from advertising revenue attracted by the paper's mass circulation. ${ }^{1}$ The Herald's approach, by contrast, was more improvised. Initial capital costs were fixed at the more modest sum of $£ 10,000$ (partly because printing was concentrated in one centre London, whereas the Citizen was to appear in two editions printed in London and Manchester). This reserve was deemed sufficient until revenue from other sources materialised. In general, financial provision was seen as contingent upon the Herald's success as a forum-style newspaper reflecting contemporary unrest. Survival was to be achieved not so much by commercial acumen as through genuine readership support. "There is no virtue in a large amount of capital", declared an early editorial. "It would be quite easy to spend the entire $£ 100,000$ for which Labour Newspapers Ltd. are asking without making the paper popular."2

In the event the Citizen began publication with a capital of $£ 30,000$ while the Herald emerged with only $£ 300$. On the Citizen's side this represented a considerable achievement. A few large institutional backers within the trade union movement subscribed enthusiastically to the Citizen share-issue scheme. Particular interest was shown by organisations with an anti-militant leadership, notably the Amalgamated Society of Railway Servants (ASRS) and the Steel Smelters'

${ }^{1}$ Arthur Henderson (Vice-chairman Labour Newspapers Ltd.) to Special Conference on "The Future of the Daily Citizen", Daily Citizen, 8 March 1913.

2 "An Unsolicited Testimonial", in: Daily Herald, 20 April 1912. 
union. Though $£ 50,000$ had been raised from such sources by publication day, rising to $£ 85,000$ by March 1913 this was still insufficient, however, to maintain the paper in existence. This was largely because revenue from advertising had been disappointing, causing a shortfall of $£ 16,000$ on original estimates. ${ }^{1}$ Circulation levels had also failed to reach expectations thereby reducing sales revenue.

From March 1913 onwards, greater publicity was given to the Citizen's vulnerable financial situation, both within the paper and at a Special Conference during the month entitled "The Future of the Daily Citizen". From this emerged a scheme for sympathetic trade unions to levy 1/- per member per annum towards the paper for the next three years. Support for this scheme was forthcoming both at union executive and local branch level. ${ }^{2}$ Greater efforts were also made to attract small-scale contributions. Hitherto the share-issue scheme designed in units of $£ 1$ had evidently deterred some smaller contributors. $^{3}$ Now, increased publicity about financial crisis prompted greater support from local organisations and individuals either in the form of single-share applications or straightforward donations. Support of this kind extended throughout the moderate wing of the organised labour movement including many ILP branches, as well as other sources of interest among non-conformist religious groupings, for example. ${ }^{4}$ Nevertheless, while local organisations and individuals predominated numerically in contribution lists, official trade union finance predominated by value. ${ }^{5}$

The Herald's early financial difficulties stemmed very largely from a fundamental desire for complete independence from the control of official labour organisation. This choice, together with the paper's subsequent militant impact, precluded any significant flow of large institutional finance to the paper. In the absence of large scale revenue from advertising or sales, the Herald relied instead on voluntary subscription or donation. Typical sources included socialist organisa-

\footnotetext{
1 Arthur Henderson to Special Conference on "The Future of the Daily Citizen", loc. cit.

2 Especially within the ASRS currently reforming as the NUR. See correspondence from the following branches, Colne (ibid., 29 March 1913), Swadlincote (1 April), Gowerton and Bo'ness (2 April), Crumlin (4 April), etc.

${ }^{3}$ Correspondence from J. P. Whitaker and "Lucky Sixpence, Walworth", ibid., 29 March 1913.

4 Nelson ILP branch launched a local 2,000 shilling fund (ibid., 2 April 1913). Other branches bought shares. Hungerford Hill Baptist Church, Nottingham sent 1 guinea on 4 April 1913, while "Four Quakers from Bristol" sent 10 shillings. 5 The distribution of contributions during March and April 1913 was as follows: Trade Unions (most national) $82 \%$, Individuals $12 \%$. Socialist organisations 6\%. Ibid., 30 April 1913.
} 
tions (usually within the BSP) and trade union branches, as well as more informal work-group or factory collections. ${ }^{1}$ Women suffragettes and Christian Socialists also helped. Large-scale support was received from a few wealthy individuals rather than labour organisations. The most important were Muriel, Countess de la Warr, a theosophist and supporter of militant women's suffrage agitation, and Henry Harben, a prominent Fabian and fellow theosophist. ${ }^{2}$ It was these two who supplied most of the finance to bridge the wide gap between the paper's liabilities and revenue from subscription, donation, advertising and sales. Harben in particular guaranteed the Herald's continuation six months ahead, and also underwrote six month contracts for the staff. Other significant individual supporters included Sime Seruya, Rev. W. H. Paine of the Church Socialist League ${ }^{3}$ and Gerald Gould. Though small-scale finance predominated numerically in subscription lists, individual donations from the Herald's wealthy patrons predominated by value. These were essential in maintaining the paper's existence during this period.

Alongside finance, the problem of reaching a mass circulation through effective distribution concerned both papers. The Citizen, well before its foundation had established circulation committees in a large number of ILP and trade union branches. These were intended to promote circulation by such means as intensive local canvassing of potential readers and news-agents. The scale of support for this initiative indicates the continued existence of a labour rank-and-file loyal to established labour leadership as exemplified through the paper. Writing of the Citizen's first six months, one ILP branch secretary declared: "A splendid lead has been given by our leaders. [...] They are doing all that is in their power. It remains with the rank and file to push up behind." 4 If official estimates are accurate, over 7,000 circulation Committees were established in support of the paper, indicating considerable rank-and-file involvement. ${ }^{5}$ Many ILP branches

1 Contribution lists are full of the following kinds of entries: "Twelve Socialist Mill Lads, Keighley" 1/-, "R. N. Torpedo Factory, Greenock" 5/6d, "A Few Sunbeam Motor Employees" 12/6d. Daily Herald, 12 and 15 October 1912 respectively.

${ }^{2}$ H. D. Harben to Raymond Postgate, 13 November 1948, Lansbury Papers, Vol. 28, appendix b ii. Harben, son of the chairman of the Prudential Assurance Company, was a key figure in the paper's early management, acting effectively as proprietor.

${ }^{3}$ A donation of $£ 150$ from Rev. W. H. Paine during a financial crisis in October 1912 comprised roughly $50 \%$ of the entire flow of donations to the paper. Daily Herald, 24 October 1912.

4 W. Harris (Bexleyheath II,P) in Daily Citizen, 1 April 1913.

5 "The Daily Citizen", in: Labour Leader, 5 September 1912. 
were mobilised like that at Nelson, Lancashire, where "The whole political machinery of the party was brought to bear" in mass houseto-house canvassing. ${ }^{1}$ Trade union participation in the campaign was also significant. One Durham miner took 30 subscription forms down the pit and came up with 30 new readers. ${ }^{2}$

While the Citizen circulation committees mobilised considerable rank-and-file enthusiasm, their work was almost exclusively organisational. They were not intended as centres for political discussion. This function was reserved for existing and appropriate organisations. All the indications are that the Citizen's supporters were content with these arrangements. The work of the Herald's circulation committees contrasted sharply with this.

Until October 1912, the Herald had adopted a somewhat haphazard approach towards the use of its readership as agents for mass circulation. An early plan to establish a system of sales promotion groups under the title of Daily Herald Scouts failed. It was only the shock of financial crisis verging on bankruptcy that prompted serious thought about the problem. An emergency appeal for increased sales and financial aid at this time, produced in response a flow of correspondence calling for a permanent organisation of Herald supporters. From this emerged the Daily Herald League, an organisation destined to play a significant, though as yet unexplored role in British labour history over the next ten years. ${ }^{3}$

The Herald League, unlike the Citizen circulation committees, combined a servicing role for the paper with wider political and social functions. Early correspondents to the Herald stressed the need for local centres of political discussion and debate in addition to the urgent task of circulation promotion. Readers in London and Manchester, for example, envisaged the League branches not only as local organisers of share-purchase and sales canvassing, but also as "centres of activity in the workers cause [...] without partisan bias" and "unprejudiced by party and personal leadership questions". A vigorous "rebel" subculture was proposed in a vocabulary stressing "Life", "Action", and "The Spirit of Revolt". The Herald's sponsors were cautious, at first,

1 Daily Citizen, 6 March 1913.

${ }^{2}$ For Citizen support in the Durham coalfield see ibid., 27 February and 17 March 1913.

${ }^{3}$ In the organisation of the 1917 Leeds Convention in support of the Russian Revolution, for example. G. Lansbury, The Miracle of Fleet Street, pp. 109, 115. Several league branches participated in the foundation of the British Communist Party. J. Klugmann, The History of the Communist Party of Great Britain, I (London, 1968), pp. 39, 42, 44.

4 Correspondence from A. W. Bradbrook, P. W. Howard, A. D. Lewis and A. O'Donnell, Daily Herald, 24-28 October 1912. 
about such proposals. They feared that dogmatic and divisive debate might proliferate within the League at the cost of the paper's survival. "I do not wish people to come who wish to discuss policy or anything else, but how to make the Daily Herald a great success", warned Lansbury. "Policy" in this sense evidently referred more to exclusive sectarian commitment, than to politics generally. Lansbury subsequently welcomed the formation of Herald leagues throughout the country, on the understanding that activists with differing viewpoints could work willingly together in support of the paper.

Most local branches accepted the spirit of Lansbury's warning, if not his confusing formulation of the problem. A wide variety of activists joined the League, or worked in conjunction with it, to promote the paper and "rebel" causes. Members were drawn in the main from the labour and socialist movements. Typical backgrounds included the BSP, ILP, syndicalist, anarchist and trade union organisations. $^{2}$ The syndicalist current within the leagues was especially important. Young activists like A. J. Cook and J. T. Murphy were involved, as well as many others who failed to achieve later prominence during and after the First World War. ${ }^{3}$ Connection with other radical social movements occurred through the leagues, particularly with sections of the militant women's suffrage campaign. ${ }^{4}$

1 Ibid., 12 November 1912.

2 Coventry DHL included Social-Democrats, Syndicalists and ILP-ers (ibid., 10 December 1912), while in Battersea, the League committee comprised members of the Church Socialist League, Clarion Cyclists and ILP, as well as the Postmen's Federation and the Electrical Trades Union (ibid., 18 January 1913). The Soho (London) branch was launched by Syndicalists, Social-Democrats and Trade Unionists, while its secretary was a former member of the Socialist League (ibid,, 7 January 1913). In Derby, the League was closely linked with the Clarion Club, while in Hammersmith, local anarchist influence predominated (ibid., 20 December 1912 and 27 February 1913).

${ }^{3}$ For the involvement of Cook and Murphy see ibid., 24 February 1913 and 26 January 1914. Cook was currently involved with the Industrial Democracy League in South Wales, a group working closely with the Industrial Syndicalist Education League, South Wales Worker, 7 June 1913; The Syndicalist, MarchApril 1913. Murphy was Sheffield secretary of the largely syndicalist-inspired Engineering Amalgamation Committee, Solidarity, March 1914. Other syndicalist secretaries of DHL branches included C. P. Robertson (Camden Town), R. L. Wigzell (New Cross), Burdett Ludlow (Coventry), Jonah Charles (Port Talbot). Detailed documentation is available in $\mathbf{R}$. J. Holton, "Syndicalism and its Impact in Britain with particular reference to Merseyside 1910-14" (unpublished D.Phil. thesis, Sussex University, 1973), pp. 486-7.

4 Ann Cobden-Sanderson of the Women's Freedom League was national Treasurer of the Daily Herald League. Daily Herald, 16 December 1912. WSPU speakers often formed part of the platform at DHL meetings, and a few local WSPU branches (especially in East London) also forged close links, e.g., Forest Gate. Ibid., 12 December 1912. 
Most Herald League branches took up the call to combine practical support for the paper with a wide range of additional functions. Typical programmes included speaker meetings, debates, outdoor propaganda and social recreation. Prominent national speakers like Lansbury, Tillett and Mann toured branches as official Herald speakers supplementing a variety of local speakers. Popular topics for discussion included the relevance of syndicalist and related movements to the current "labour unrest" under such titles as "Socialism v Syndicalism", "Socialism and Strikes", and "Industrial Unionism". Debate upon recent social welfare legislation was featured under headings such as "Bismarck and Lloyd Georgism". The recreational side of Herald League activity was organised under the theme of "Rebels Revels" and "Joy Nights". It often proceeded in conjunction with the existing Clarion movement featuring music and cycling. The Daily Herald leagues through their breadth of membership and provincial coverage, were clearly a significant element of the contemporary dissident left. The peak of their activity probably occurred in the winter of 1912-13 in the aftermath of the Herald's financial crisis, but branch activity continued in many areas after the emergency had passed. On the eve of war the fortunes of the League were once more on the upgrade. ${ }^{1}$ The Herald through its relationship with the Herald leagues undoubtedly exerted a considerable influence as an organiser of activist endeavour throughout this period.

The onset of the First World War brought considerable changes to both labour dailies. Worsening financial problems were largely responsible for the Citizen's eventual collapse in the summer of 1915 , and for the Herald's contraction to weekly status from September 1914. The challenge of war also posed difficult political problems for both papers. Their contrasting responses demonstrate the continuing rivalry between Herald and Citizen as representatives of different ideological currents within the labour movement and society.

The Citizen's wartime patriotism marked a further defeat for radical IIP influence over the paper. Official constraints upon Dilnot's ultrapatriotic leanings issued by the Board of Directors could not prevent a steady shift in the paper's emphasis. ${ }^{2}$ During late July and early August, the Citizen's leaders still reflected general ILP aversion to

1 Between June and August 1914, 11 new league branches were formed in addition to the 40 or so most active branches already in existence. These figures refer only to individual branches mentioned in the paper at this time. A number of others undoubtedly existed during the period if subsequent internal evidence is an accurate guide.

2 Bruce Glasier, Diary, 6 August 1914. 
British involvement in likely hostilities under headings like "Down with War", and "Britain Must Keep Out". And though the fact of war was soon accepted, the need to "Allay mere jingo-clamour" was cogently expressed. ${ }^{1}$ By early autumn, however, the experience of military conflict had produced a more exuberant patriotic approach. This not only upheld official Labour Party support for recruitment, but also involved glorification of the contribution of the common soldier as the backbone of the war effort. ${ }^{2}$ It was only a short step from sentiments such as these, to a mystification of the horrors of war in the interests of recruiting propaganda. By January 1915, the paper was printing uplifting accounts of trench fighting. ${ }^{3}$ ILP protests against the Citizen's pro-war stance had little effect. Critical opinion received little coverage after early August. In March 1915, three ILP representatives were ousted from the Board of Directors. This was largely a product of policy disagreement, but was also in part connected with a financial re-construction of the paper. ${ }^{4}$

The Citizen's financial situation worsened considerably after the outbreak of war. Sales began to decline during the autumn, while advertising remained difficult to attract. More important, however, was the adverse effect of a legal judgement of March 1915 which jeopardised the vital flow of large-scale trade union finance to the paper. Trade union contributions were now interpreted as expenditure for political objectives, insofar as the Citizen was committed to support the Labour Party. ${ }^{5}$ This was unlawful under the Trade Union Act of 1913 unless specifically agreed by the union membership. The effect of this judgement was to disrupt financial provision pending alterations in the constitution of Labour Newspapers Ltd. to non-political friendly society status.

The ousting of the ILP's representatives on the Board during this reorganisation left the Trade Union interest in control. This was dominated by the National Union of Railwaymen and the Steel Smelters. These two unions had been largely responsible for the continued existence of the Citizen since $1914 .^{6}$ By May 1915 however, the financial

1 "What Labour Can Do", in: Daily Citizen, 7 August 1914.

2 Diogenes, "Undelivered Letter to Private Tommy Atkins", ibid., 4 September 1914.

3 "Those who hesitate to enlist because of what they have heard about trench fighting should look at the picture on the left, which shows soldiers who have just left the firing line, after being up to the knees in mud. They are cheerful and ready for more." Ibid., 20 January 1915.

4 Bruce Glasier, Diary, 10 and 12 March 1915.

5 In Bennett $v$. The National Amalgamated Society of Operative House and Ship Painters and Decorators.

${ }^{6}$ Bruce Glasier, Diary, 29 April and 23 July 1914. 
burden was proving too great. Though rank-and-file subscriptions to the paper continued on a wide scale during the next month, this was insufficient to keep the Citizen solvent. ${ }^{1}$ Last minute attempts by ILP members to obtain Quaker finance for a re-vamped Citizen on "Socialist, pro-peace" lines failed. ${ }^{2}$ The paper finally bowed out on June 5 th.

The political influence of the Daily Herald on rebel opinion was reduced but by no means undermined during the early part of the war. Though circulation soon began to fall and newsprint became rationed, the subsequent contraction to weekly status was not entirely disastrous. The Herald's impact as a radical forum remained significant, if only because of its almost unique support for the anti-war position. On the eve of the war, the Herald, in company with its official rival, had declared against British involvement. Its opposition stemmed not only from a moral abhorrence of war, but also from a critique of the anti-democratic implications of secret diplomacy. The latter dimension was largely absent from the Citizen. Once war was declared, the Herald, unlike the Citizen also sought to analyse the significance of hostilities for the international labour movement. The resulting verdict was one of sadness and pessimism.

"The whole situation shows in fearsome wise, how little the millions are free, physically, socially, intellectually, mentally, or otherwise. It is a stupendous illustration of slavery, exterior and interior. A few war-lords and diplomats dwelling with abstractions and working in the dark, have disagreed or lost their heads, and forthwith they are able to disorganise all Europe. [...] And now we are told that momentous causes are at stake, that rights and privileges never enjoyed in practice are in jeopardy. Hosts of wage-slaves believe it all."3

While the wartime Herald became a rallying point for anti-war opinion, this did not entirely preclude its continuation as a forum for debate. Both G. K. Chesterton and Ben Tillett continued to write for the paper even though they supported Britain's involvement in the war. A protracted debate between Chesterton and Lansbury over the causes of the war was a particular feature of debate during August and September 1914. Chesterton, unlike Lansbury, located the "blame" not within the international capitalist community, but solely within Germany around "the firm of Krupp and Hohenzollern". He viewed

1 The scale of rank-and-file support organised through a " 100,000 Shilling Fund" was considerable. Trade Union branches and Trades Councils played the most important role.

Bruce Glasier, Diary, 22 May 1915.

3 "The Ark and the Blood Deluge", Daily Herald, 10 August 1914. 
the war effort in fact as part of an anti-capitalist struggle and not as a supra-class conflict between nations. "I feel quite certain that a successful blow at the Krupp firm and its dependants, the Hohenzollern princes, would break the philosophy of capitalism all over the world". ${ }^{1}$ Chesterton's billing as a leading Herald writer reflected his importance to Lansbury as a means of attracting disaffected Liberal opinion away from the strongly pro-war party press (notably the Daily News). ${ }^{2}$

The Herald's appearance as a weekly changed the balance of emphasis away from news reporting to feature articles. New writers like Harold Laski and Gerald Gould were added alongside Lansbury and Chesterton. The day-to-day activities of the much depleted rebel movement were still recorded nonetheless. The Daily Herald League remained in existence if on a much reduced scale. Its main centres of support were for the moment restricted to London and Scotland. The East London sections for example continued to work closely with the militant suffrage and social reform agitation of Sylvia Pankhurst and her associates. Scottish branches in Glasgow and the Dumfries-Lockerbie area continued to hold speaker meetings and did much to hold up weekly circulation figures. ${ }^{3}$

By the time of the Citizen's collapse in June 1915, the Herald was only slowly recovering its élan after the dislocating and demoralising impact of the war. Though the two papers held sharply contrasting positions on the issue of support for the war, the bitter edge of conflict between them had been considerably muted after August 1914. The Citizen, in spite of its patriotism, was now the only remaining labour daily. As such, the Herald lamented its demise in 1915. Experience of the domestic war effort hitherto had demonstrated the increasing scope for popular newspapers as agencies of propaganda and more insidious forms of social control at the expense of working class and socialist initiative. Herald opinion became more clearly conscious of this process than hitherto.

"The Press is more powerful now than ever before", wrote a contributor on the collapse of the Citizen. "The Press Gang which maligns the worker, sneers at the idealist and kow-tows to the advertiser, is a far more sinister enemy of human liberty than any current press gang that carried off cannon-fodder to the King's Navy. [...] They get their readers in a state of half-baked ignorance and keep them there. The new Sunday illustrated papers are typical and triumphant. They

1 G. K. Chesterton, "The Villain of the Peace", ibid., 15 August 1914.

${ }^{2}$ G. K. Chesterton, "To A Reader of the 'Daily News"', ibid., 8 August 1914; also leader 'Resurgam', ibid., 19 September 1914.

3 Progress in Scotland can be traced through Weekly Herald between October and December 1914. 
demand no effort, they give no detail, they inform by headlines, and they circulate in myriads." 1

The problem of assessing newspaper influence is a complex one. This is especially true in the case of the labour press where attention was directed more towards labour and progressive opinion in the country than to government policy makers. Apart from the problem of locating the opinion of the readership, there remains the difficulty of identifying the ways in which the labour press may have exerted an influence. Both papers operated in a less tangible, more diffuse manner than most other contemporary labour institutions. Raymond Postgate recognised this in his picture of the Herald as an organisation which "passed no resolutions, and fought seats at no elections, but was always there, persuading, informing and protesting". ${ }^{2}$ There is, in addition, the problem of evaluating the impact of largely non-verbal newspaper material, notably the widely remembered cartoons of Will Dyson. Difficulties such as these militate against judgement of newspaper success or failure.

In purely quantitative terms, the performance of the labour dailies between 1912-14 was uneven and erratic, but certainly far from insignificant. At their peak, both the Daily Citizen and the Daily Herald achieved average gross daily circulation figures of 200,000250,000. Peaks of this kind were, however, only recorded for limited periods. More typical circulation figures for the pre-war years range from 130,000-200,000 in the case of the Citizen, and 50,000-150,000 for the Herald. ${ }^{3}$ Circulation levels of this magnitude were generally less than the larger established London dailies, but by no means trivial. While Northcliffe's Daily Mail and Daily Mirror had achieved a daily circulation of between 750,000 and 1 million by $1912,{ }^{4}$ the performance of the remaining papers was less impressive. The Daily Neres, for example sold around 350,000-400,000 copies per day at this time, the Daily Express over 300,000, and the Daily Telegraph around 250,000 and declining.

Though the Herald and Citizen sold less copies than most other leading London dailies, it is probable that their sales among manual working class readers were proportionately, and possibly absolutely

1 I. Brown, "The Press Gang", ibid., 12 June 1915.

2 R. Postgate, “A Socialist Remembers - 1", in: New Statesman, 9 April 1971.

${ }^{3}$ Available circulation statistics are patchy in coverage over time. Useful sources include scattered references in the two papers themselves, contemporary manuscript sources, and autobiographical recollections.

4 The following data are taken from A. P. Wadsworth, "Newspaper Circulations, 1800-1954", in: Transactions of the Manchester Statistical Society, 1954-5, p. 35. 
greater than those achieved by the typical established daily. Raymond Williams has recently argued that large scale expansion of the daily newspaper into the working class did not occur until after the First World War. ${ }^{1}$ Even the "mass" Daily Mail sold primarily to "small businessmen, clerks and artisans". Even allowing for substantial nonmanual working class readership of the labour papers, it is clear from internal evidence that industrial working class support among readers was crucial.

Fluctuations in circulation statistics provide some additional insight into the qualitative impact of the two labour dailies. The Herald's sales, for example, varied to some extent with the pattern of industrial unrest. An upsurge in circulation during the 1912 London transport strike (during which the paper acted as official strike organ) is a case in point. Otherwise sales of both papers appear to have fluctuated with general political conditions, showing a marked if temporary upsurge during moments of national crisis, notably the outbreak of war. In the Herald's case, however, it is interesting that circulation had been rising since the early months of $1914,{ }^{2}$ well before the war emergency and at a time when few major industrial disputes were in progress (with perhaps the exception of the 1914 London building trades lock-out). This upswing, also registered in the affairs of the Daily Herald League, provides some support for the notions of expanding militancy though hardly of imminent social breakdown. Quantitative evidence is of little further help in interpreting the meaning of circulation trends. In particular it gives no indication of whether the two labour dailies were leading or following opinion, that is of the direction of "influence" between newspaper and readership. This question can only be approached through a close study of the inter-action between newspaper promoters, editorial staff, contributors and readers. Such a study unfortunately reveals more about the Herald insofar as its supporters were encouraged to participate fully if the paper was to succeed in its chosen role. With the Citizen, the readership was assigned only a subsidiary dependent function. Initiative lay with moderate and pragmatic sections of the Labour Party and trade union leadership. Within these limits, however, a number of conclusions do emerge.

The Herald clearly stimulated and reflected surrounding opinion. Its function as a wide-ranging forum for dissident views was largely successful in attracting many disparate currents of radicalism. This undoubtedly helped to create a number of important cross-currents within rebel opinion. These embraced ideological debate, tactical discussion and the organisation of common activity largely through

1 R. Williams, The Long Revolution (Pelican ed., London, 1965), p. 227.

2 Daily Herald, 5 August 1914. 
the Daily Herald leagues. Such co-ordinating functions were, however, dependent on initiative from all levels, not merely from the paper's sponsors. In this way, the Herald exercised considerable influence as an organiser of dissident opinion. By neglecting this dimension to the labour unrest, most previous writers have misconceived the largely inter-related character of contemporary radicalism, and failed to explore an important indicator of the sizeable scale of militancy. Recent attempts to minimise the extent of unrest by concentrating solely on institutional evidence are therefore inadequate and misleading.

The foundation and short-term survival of the Citizen, on the other hand, testifies to the continuing importance of non-militant labour attitudes within the pre-war years of unrest. The Citizen, as an official organ for the defence of orthodox labour authority was intended to lead rather than follow sympathetic opinion. The evidence of circulation performance and involvement with servicing work suggests, contrary to existing views, ${ }^{1}$ that the paper succeeded in gaining the allegiance of a large number of non-rebel rank-and-file supporters. These ranged from Labour Party loyalists to frustrated ILP radicals. Even if the Citizen was "smug, common and ultra-official", in the words of Beatrice Webb, it still played an important role in holding together various strands of moderate opinion in the face of expanding militancy elsewhere.

1 M. Beer, A History of British Socialism, II (London, 1929), p. 380; Beatrice Webb's Diaries 1912-24, p. 23. 